\title{
Rölyef Heykel
}

\author{
Arzu ÇAKIR ATIL *
}

Özet

Rölyef heykel, zemin yüzeyinin aşağısında ya da üstünde farklı derinliklerde gerçekleştirilen heykel formudur. Zemin, rölyef heykelin referans noktasıdır ve resmin yanılsamalı iki boyut algısıyla heykelin üç boyut gerçekliğini bir arada kullanmamızı olanaklı kılar. Zeminden uzaklaşma boyutuna göre rölyef heykeli ancak çok genel bir tanımlamayla kesme, alçak, orta ve yüksek rölyef şeklinde çeşitlere ayırabiliriz.

Rölyef heykel, dünyanın her bölgesinde ve her dönem vardır. Kesme rölyeften serbest heykele uzanan derinlik boyutu, yüzyıllardır sanatçılara geniş bir uygulama alanı oluşturmuştur. Bu temel sanat formunun figüratif örnekleri, geleneksel heykeltıraşlık ve sanat eğitimi açısından, derinliğin yanılsamalı ve gerçek boyutuyla ilgili, önemli bir deneyim alanı açar.

Makalede, figüratif rölyef heykelin temel özellikleri, çeşitleri ve heykeltıraşlık açısından 20. yüzyıla kadar niteliği önemli örnekler üzerinden incelenmiştir.

Anahtar Sözcükler: Rölyef, Heykel, Zemin, Derinlik, Form.

\section{Relief Sculpture}

\section{Abstract}

Relief sculpture is a process in which patterns have been formed in a variety of depths from superficial to deep surfaces. Surface is a point of reference to relief sculpture allowing us to use illusional perception of two dimensional pictorialness and a reality of three dimensional sculpture in combination. Relief sculpture can be divided into such forms as cutting (coelanaglyphic) low, middle and high reliefs considering recesses and protrusions from surface into depths

Relief sculpture has been universally ubiquitous in every period of time. Dimension of deepness from cutting relief from freestanding sculpture has been providing artists with a wide range of practices for centuries on. Figurative examples of this form of art create an important field of experience concerning illusional and realistic dimensions of deepness in terms of traditional sculpturing and artistic education.

In this paper, the basic features of figurative sculpture relief, its types and quality in terms of sculpture are be examined through significant examples until 20th century.

Keywords: Relief, Sculpture, Surface, Depth, Form. 


\section{Giriş}

Rölyef heykel, bir düzleme bağlı olarak gelişen, bu düzlemin altında ya da üstünde, resim ve serbest heykel arasındaki derinlik alanında varlık gösteren yani iki boyut (düzlem) ve üç boyut (hacim) içerisinde tartışılan ancak abartıl, gelişmiş resim, az gelişmiş heykel ya da bunların bir karışımı gibi görülmemesi gereken bir sanat formudur.

Rölyef, “Latince 'relevare', yükseltmek kökünden gelir. Üç boyutlu heykele özgü niteliklerin yanı sıra, perspektif gibi iki boyutlu resimsel öğelerden de yararlanılır. Mimari bir bezeme türü olarak en çok yapı ve duvar yüzeylerinde görülür. Ayrıca anıt, kaide, lahit, mezar taşı gibi büyük boyutlu öğelerin yanı sıra kilise eşyası, mobilya, sikke gibi irili ufaklı birçok kullanım eşyasına da uygulanabilir" (Rona, 1997: 925). Heykel terimi tarih boyunca farklı anlamlara sahip olmuştur. Kelime Latince oyma, kesme, kazıma anlamına gelen 'sculpere' kökünden gelir. Antik Yunan'da bu terim, aynı zamanda rölyef (sığ derinliğe sahip) ve etrafında dolaşılabilen, kendi kendine ayakta duran (free-standing: serbest heykel) heykellerin yapımında kullanılan yumuşak malzemeyi modelleme yöntemini de kapsamaktadır (Ocvirk, 2015: 39). 'Rölyef heykel' olarak adlandırılmasının nedeni, heykel modellemesinde üretilen benzer çözümleri kullanmasından kaynaklanmaktadır.

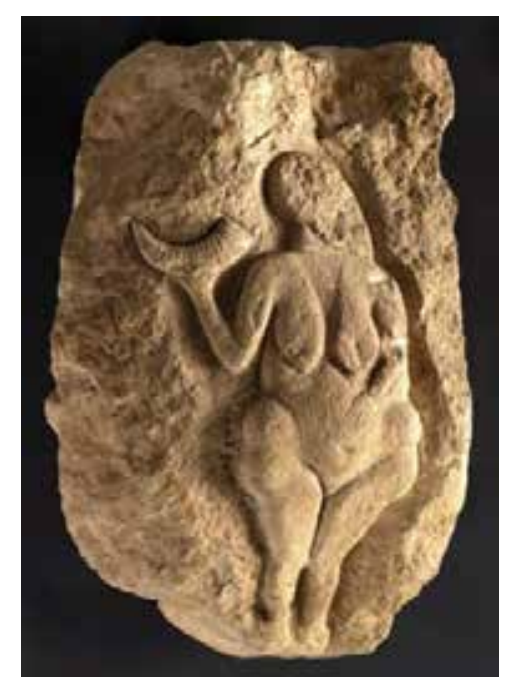

Resim 1. Laussel Venüsü (M.Ö 23.000), Paleolitik, Fransa.
Oyulan, dökümü yapılan, çekiçle şekil verilen, birleştirilen her türlü malzeme rölyef heykel için yüzey alanı oluşturabilmektedir. Büyük ölçekli mimari rölyefler, yumuşak malzemelerle biçimlendirildikten sonra bronz, terracotta ya da diğer dayanıklı malzemelere aktarılarak bina yüzeyine monte edilmekte ya da noktalama aleti ile taşa veya ahşaba aktarılmaktadır.

Arkadan delme ve çekiçle vurma ile sağlanan rölyef oluşturma yöntemi, kupa ya da zırh gibi ürünlerde görülebilmektedir. Madalyonlar ve bozuk paralar "intaglio" denen teknikle, negatif imgenin çelik bir döküm şeklinde oyularak sonrasında pozitif imgelere aktarılmasıyla oluşturulmaktadır (Boström, 2004: 1399).

Rölyef heykel alanında yapılanlar, hem batı hem doğu kültürlerinde paleolitik döneme kadar tarihlenen eski bir geçmişe sahiptir (Resim1). "Rölyef heykeller içinde, figüratif ve soyut tarzda biçimlendirilmiş örnekler vardır. Figüratif olanların çoğu Yunan, Roma, Romanesk ve Gotik mimari ve Rönesans'la birlikte Avrupa heykeli ile ilişkilidir. Soyut örnekleri Antik Yunan, Keltler, Meksika, Viking ve İslam sanatlarında görmek mümkündür." (Visual Arts Encyclopedia).

Sanat tarihinin neredeyse her döneminde görülen ve çok geniş bir yer kaplayan rölyef heykel konusunu, temelde biçimlendirme açısından ele almak, öne çıkan dönemsel özelliklere vurgu yapmak, makalenin sınırlarını oluşturmuştur.

Makalede, Avrupa heykeli ile ilişkilendirebileceğimiz, figüratif rölyef heykelin bir sanat formu olarak temel özellikleri, çeşitleri ve heykeltıraşlık açısından 20. yüzyıla kadar niteliği önemli örnekler üzerinden incelenmiştir.

\section{Rölyef Heykel Çeşitleri}

Rölyef heykel, iki ve üç boyutlu sanat formlarının özelliklerinin pek çoğunu içeren, bir zemin(fon-duvar) üzerinden yükselen, zeminden aşağıda gerçekleştirilen ya da her iki durumun da kullanıldığı form olarak açıklanabilir. Bu tanım, aynı zamanda rölyef çeşitlerini de belirler. Ancak genel çerçevede kesme, alçak, orta ve yüksek rölyef şek- 
linde yapılabilecek sınıflandırma bile durumu tam olarak tanımlamaya yetmez. Çünkü rölyef düzlemine giren ve çıkan her formun yükseklik derecesi, birbirinden farklı özellikler göstermektedir ve üç boyutlu bir mekanda zeminden aşağıda gerçekleştirilen rölyeften(kesme), serbest heykele kadar uzanan derinlik boyutu, genel kategorilere uymayacak çeşitlilikte ihtimaller sunar.

Bu geniş varyasyon alanı içinde, mekan içinde heykel gibi kütlesel şekilde ayakta duran ancak dört bir tarafı rölyeflerden kurulu Meksika taş figürleri, bir duvara tutturulmuş ancak üç boyutlu heykel gibi görünen Hint ve Ortaçağ oymaları ve rölyefle üç boyutlu heykel arasındaki gibi bir ayrımın kaçınılmaz olduğu pek çok heykel formu vardır (Rogers, 1969:155).

Rölyefler, resmin bazı özelliklerini, tamamen heykele özgü özelliklerle birleştirerek, resmin yanılsamalı görsel mekanı ile heykelin gerçek mekanı arasındaki derinlik alanında var olur. İzleyenin bakış açısı, resimsel derinliği hissettirecek kompozisyonun seçimi, çizimi ve perspektif açıdan formların birbirini takip ederek zeminden ne kadar uzaklaşıp yaklaşacağı ile ilgili verilen kararlar gibi, resim yaparken kullanılan bazı yöntemler rölyef heykelde de kullanılmaktadır. Tüm bu organizasyon bir referans düzlem üzerinden gerçekleştirilir. Rölyefte fon ya da arka plan(duvar), derinliği ele alış biçimimizi gösteren bir referans noktası, hem görsel hem fiziksel zemindir. Rölyefler, arka plan düzlemi söz konusu olduğunda, bu düzleme tutturulmuş form olmaktan çok, ona gömülmüş veya birer çıkıntısıymış gibi öne çıkan özellikler göstermektedir.

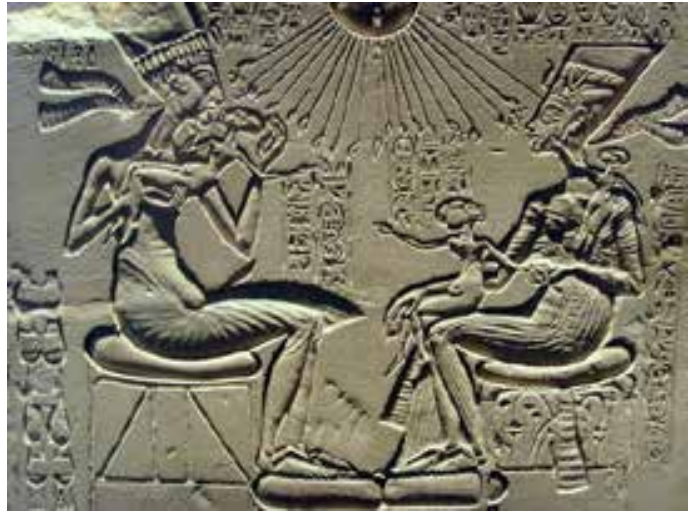

Resim 2. Akhenaten, Nefertiti ve Çocukları.
Rölyefte başvurulan resme ait özellikler, heykelde yakalanması zor bazı fırsatlar sunar. Kompozisyonu oluşturan parçaların bir ağırlık merkezi olmadığından (taşıyıCISI, zemin düzlemi olduğundan), fiziksel denge, destek ve malzeme direnci ile ilgili sorunlar, heykelden farklıdır. Rölyef alanı, resimde olduğu gibi, gerçekte ağır ya da yoğun parçaların zayıf formların üzerine gelerek, biçimlendirilmesini olanaklı kılar. Kalabalık insan grupları, savaş sahneleri, iç mekanlar, binalar, manzara ve gökyüzü, rölyef heykelde kolaylıkla kullanılabilir. Bu durum sanatçıya, heykelde gerçekleştirilmesi zor kompozisyonları bir düzlem (duvar) üzerinde uygulama kolaylığı verir.
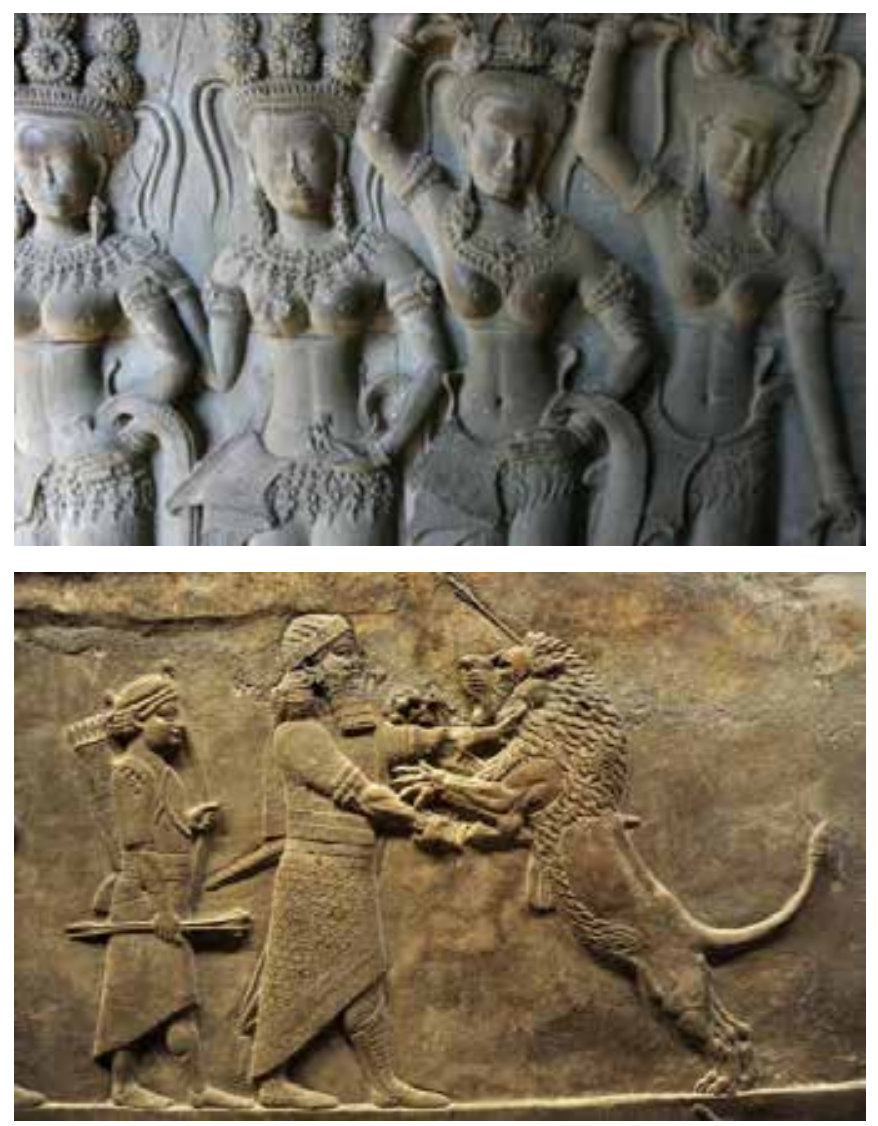

Resim 3. Apsara Dansçıları, Oyma, Angkor Wat Wall.

Resim 4. Ashurbanipal Aslan Avı (M.0̈ 645-635) Ninevah, Irak.

Rölyeflerin heykel ya da resim arasında hangi derinlik düzeyinde kaldığı sanat tarzlarına göre farklılık göstermektedir. Kesme ya da 'coelanaglyphic' olarak ad- 
landırılan Mısır rölyef heykeli, zeminden dışarı doğru değil tersine her nesnenin dış çizgileri ve kontürleri etrafında zeminin içine oyularak yaratılan, gölgeyle vurgulanmış alanlardır (Resim 2). Mısır rölyeflerinde, kontürler son derece belirgin ve vurguludur. Mısır çizgilerinin keskinliği ve belirginliği, dış kenarlarının ışığı yakalama şekliyle belirlenir. Mekan anlatımı, formların tepeden, üst üste görünümü, perspektif gibi derinlik izlenimi veren hiçbir şey yoktur. "Bir masa üstten görünüş olarak, ya kare ya da yuvarlak olarak gösterilmiştir. Fakat hiçbir zaman bir eşya bir noktadan perspektif görünüş içinde gösterilmemiştir. Bu rölyeflerden çıkarılan perspektif nesne biçimlerinin bir yüzeyde sıralanarak icra edilmesine dayanmaktadır" (Turani, 2003: 59). Çizgisel özellikleri nedeniyle incelikli bir etkiye sahipmiş gibi görünmesine karşın yüzeysel bir form biçimlendirilmesi vardır.

"Antik ya da eski uygarlıkların alçak iç mekan rölyefleri, çoğunlukla çizgisellik açısından şaşırtıcı bir başarı ve parlaklık düzeyi göstermektedir. Angkor Vat'taki kıvrımlı rölyefler ve Asurlulara özgü alçak rölyefin güçlü, sert hatları, birbirinden tamamen farklı ruh hallerini yansıtan iki örnektir" (Rogers, 1969: 162) ( Resim 3-4).

'Statiacciato' ya da düz (alçak) rölyef diye bilinen formda, farklı resim yöntemleri kullanılmaktadır. Tüm rölyef çeşitleri içerisinde en sığ ve zeminin resimsel özellikleri ile malzemeyi çok ince derinlilerle kaynaştıran tipidir. Donatello'nun 'Anahtarları Aziz Peter'e veren İsa' adlı çalışması, fiziksel anlamda derinliğin en az olduğu alanlarda, üç boyutlu derinlik yanılsaması yaratmak için hem resim hem de üç boyut özeliklerinin neredeyse tamamının kullanıldığı önemli bir örnektir (Resim 5).

Rölyef heykelde boyutun büyümesi, zeminden uzaklaşma (yükselme), hacmi daha etkili kullanma imkanı verme ve yüzeylerin biçimlendirilmesi için daha büyük alan açar gibi görünmekle birlikte, çok sınırlı derinlik alanı içinde de vurgulu plastik etkiler elde etmek mümkündür. Aslında heykeltıraşlık açısından rölyefin büyüsü de bu noktadadır. Bazı heykeltıraşlar, Donatello'nun rölyef çalışmasında olduğu gibi, sınırlı bir derinlik olanağı ve alanı içinde öyle bir duyarlılık ve biçimlendirme hassasiyeti ile çalışırlar ki yüzeyden çok uzaklaşmış yüksek rölyef örneklerinde yakalayabileceklerinden daha güçlü bir hacim etkisine ulaşabilirler.

Donatello'nun 'Anahtarları Aziz Peter'e veren İsa' ça-

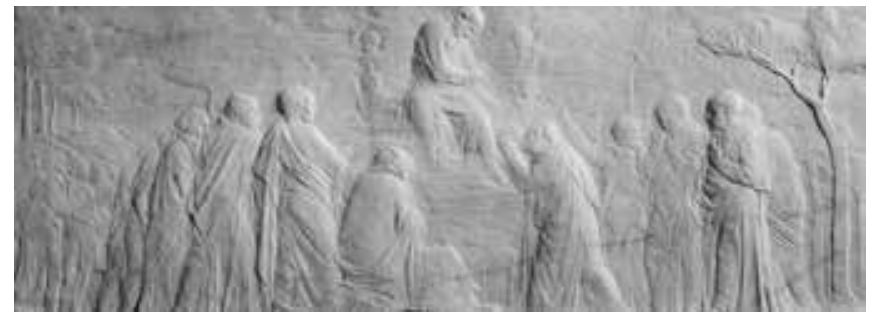

Resim 5. 'Anahtarları Aziz Peter'e veren İsa', Donatella, 1428-30, mermer, Floransa- İtalya. Victoria and Albert Müzesi, Londra.

lışmasının tüm yüzeyinde, rölyefle zemin arasında hiçbir ayrım ya da kopuş bulunmamakta, tersine her ikisi de birbiriyle kaynaşmış izlenimi uyandırmaktadır. Rölyef zemini tamamen biçimlendirilip, işlenerek düzlüğü yok edilmiş, perspektifin de etkili kullanımıyla, rölyef genelinde sonsuzluk etkisi yakalanmaya çalışılmıştır. "Giderek ufalan bulutlar, zeminin içe doğru gerileyen, üst üste binen girinti, çıkıntı ve kıvrımları, ağaçların oluşturduğu hattın sağladığı derinlikli perspektif ve arka planda zarif ve özenli şekilde oyularak çıkarılan kent gibi şeylerin tümü, içinde figürlerin oluşturduğu hareketin meydana geldiği sınırsız bir resimsel üç boyutluluğu ya da mekan algısını çağııştırmaktadır." (Rogers, 1969: 162). Neredeyse, resim yaparken yakalayabileceğimiz ışık ve gökyüzü efektleri bile forma aktarılabilmiş̧ir. Çalışma, ışık-gölge dağııımı ve yüzey modelleme açısından hassas bir heykeltıraşlık ustalığını göstermektedir.

“Donatello’nun kutsal sahneyi betimlemedeki yeni tarzı, geçmiş dönemlerin övüncü apaçık dengeyi birçok yönleriyle alt üst ederken, Ghiberti açık ve ölçülü kalmaya özen göstermektedir. Donatello'nun yaptığı gibi bize gerçek mekan izlenimi vermez. Ayrımsız bir arka düzlemde, belli başlı figürleri belirginleştirerek, derinliğe şöyle bir değinip geçmeyi yeğler." (Gombrich, 1989: 187) (Resim 6).

Desiderio da Settignano, Donatello'nun kurduğu dramatik anlatımlı rölyeflerinden yararlanmış, alçak rölyef biçimlendirmesini etkin bir şekilde kullandığı örnekler vermiştir (Resim 7).

Rölyef heykelin tamamında algımız bizi, kompozis- 

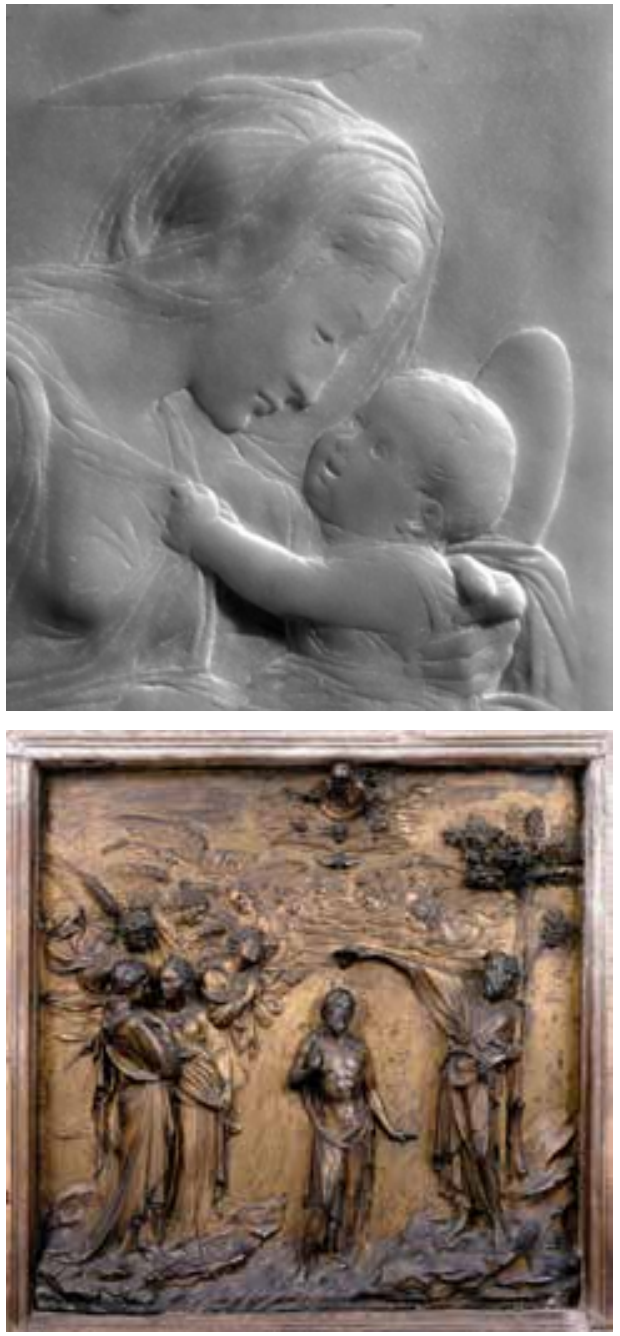

Resim 6. 'İsa'nın Vaftiz Edilişis', Ghiberti, 1427, tunç.

Resim 7. 'Meryem ve İsa', Desiderio da Settignano, 1460, mermer, İtalya.

yonun her parçasının zeminle buluştuğu noktalara yönlendirir. Formlar yumuşak, kademeli ya da düz şekilde zeminle buluşuyorsa, rölyefin duvara yerleştiği ve tutunduğunu hissederiz. Dik, keskin kenarla sert bir geçiş ise, formları bağlı bulundukları ya da içinden oyuldukları zeminden ayırır ve zemin üzerine sonradan eklenmiş bağımsız heykeller varmış gibi bir izlenim uyandırır. Rölyefteki heykel etkisini arttırmak için formlar, alttan kesilerek biçimlendirilir. Bu önemli teknik işlemin pratikliğini, hem rölyef hem de heykel modellemesinde yaygın şekilde görürüz. Ayrıca alttan kesme işleminden, tali diyebileceğimiz daha küçük formların ana kütlelerden ayrılması aşamasında, heykele derinlik sağlamak için özellikle giysi formlarının biçimlendirilmesinde yararlanırız. Alttan kesim, formların gerisinde ya da arka kısmında yontu işlemi yaparak formların zeminden gerçek anlamda koparılmasına yönelik ilk adım olarak görülebilir. Bu işlem heykeltıraşın biçimlendirdiği yüzey ve çizgilerin, formların arkasından dolaşıyormuş gibi görünerek daha fazla derinlik etkisi kazanmalarını, rölyefle zemin arasındaki gölgelerin de yakalanmasını sağlar. Görsel olarak gölgeler, rölyefi zeminden dışarı, izleyene doğru fırlatır. Yüksek rölyefler ait oldukları duvarla hiçbir bağlantıları yokmuş izlenimi verircesine alttan tamamen oyularak ve tam anlamıyla zeminden koparılarak, ana kısımlar ya da baş, kol, bacak gibi parçaları bağımsız heykel formlarına dönüşebilirler (Rogers, 1969: 158). Bu, özellikle orta ve yüksek rölyeflerde, hacim özelliklerini vurgulamak için başvurulan bir biçimlendirme yöntemidir.
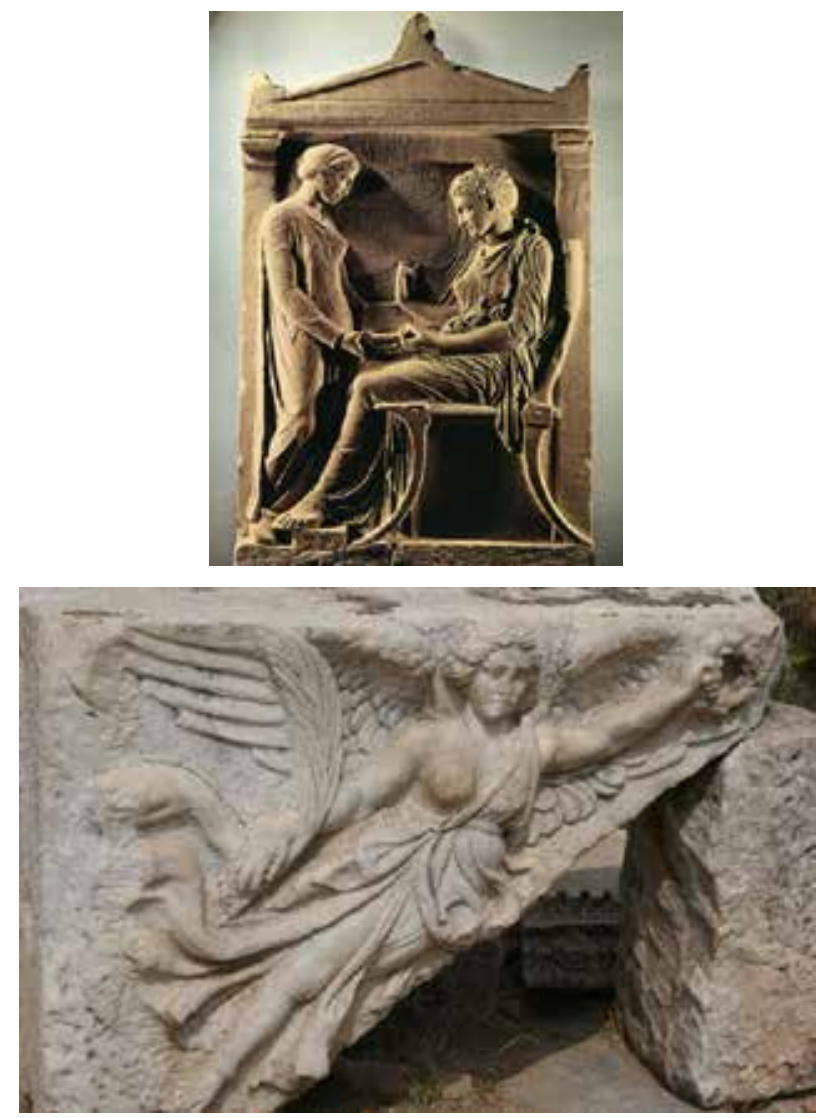

Resim 8. Hegeso, M.Ö. 400, Ulusal Arkeoloji Müzesi, Atina

Resim 9. Efes, Nike (Zafer) tanrıçası tapınağı kanatlı melek figürleri. 
Klasik antik dönemin rölyeflerinde duvarın oluşturduğu düzlem(zemin) dokunulmaz ve sadece yapının gerçek tasarımının değerlendirilebileceği bir referans, taşıyıcı gibi işlev görmektedir. Yanılsamalı resimsel mekanın bulunmadığı Yunan rölyefinde, derinliği vurgulamak adına formların üst üste ve birbiri ardı sıra gelecek şekilde modellenmesinden sık sık yararlanılmaktadır. Neredeyse tamamen heykele özgü efektlerden, zeminden öne doğru, kompozisyonun farklı derecelerinde yararlanılmaktadır. Efektler, genelde biçimlendirilen parça alttan ve arkadan kesilerek sağlanmakta, formları daha vurgulu şekilde ortaya çıkarabilme adına yapılan bu modelleme işlemiyle rölyefin güçlü plastik etkisine, ulaşılabilmektedir.

Parthenon frizlerindeki Yunan rölyefleri, Hegeso, Ktesileos ve Theano mezar taşları, Efes'teki Artemis tapınağı sütun kaidesi ve Nike (zafer) tanrıçası tapınağı kanatlı zafer melek figürleri gibi rölyef heykeller, bu plastik özellikleri barındıran tipik örneklerdendir (Rogers, 1969: 163) (Resim 8-9).

Hint rölyef heykelinde de yontu yöntemlerine daha fazla ağırlık verilir. Alttan kesilerek fondan koparılmış bu rölyef heykeller, derinlik yanılsaması yaratmadan neredeyse heykelleri kadar doluluğun farkında olarak biçimlendirilmişlerdir. Hacim etkisini artıran yuvarlak formların üzerinden dönen, kemer gibi detaylarla doluluğa vurgu arttırılmış, izleyende dokunma uyandıran etkiler yakalanmıştır.

Roma rölyeflerinde, heykellerinde görülen kumaşla vücut biçimini saklama görülmez. "Vücut parçaları ile elbise kıvrımları, optik bir izlenimle değil, adeta inşa edilmişlerdir. Rölyeflerde stilize edilmiş şekilde gösterilen nebat ve ağaçlar, kaz inek ve kuzular, kompozisyonda ayrı planda olmalarına rağmen, perspektif görüşe tabi olmamışlardır. Bu yüzden maniyere olmuş bir klasizmin bütün Roma rölyef sanatını etkilediği anlaşılır." (Turani, 2003: 198) (Resim 10). "Figürler derin şekilde kesilerek bakan kişinin göz seviyesi üzerinde açıkça görünür hale getirilmişlerdir. Sınırlı resimsel alanın fiziksel engellerinin ötesinde tasvir (betimleyici) unsurlarının uzantıları, yer yer duvarların üzerinden dışarı ya da ileri doğru uzanan figür başlarının gösterilmesiyle vurgulanmıştır." (Avery, 2015).
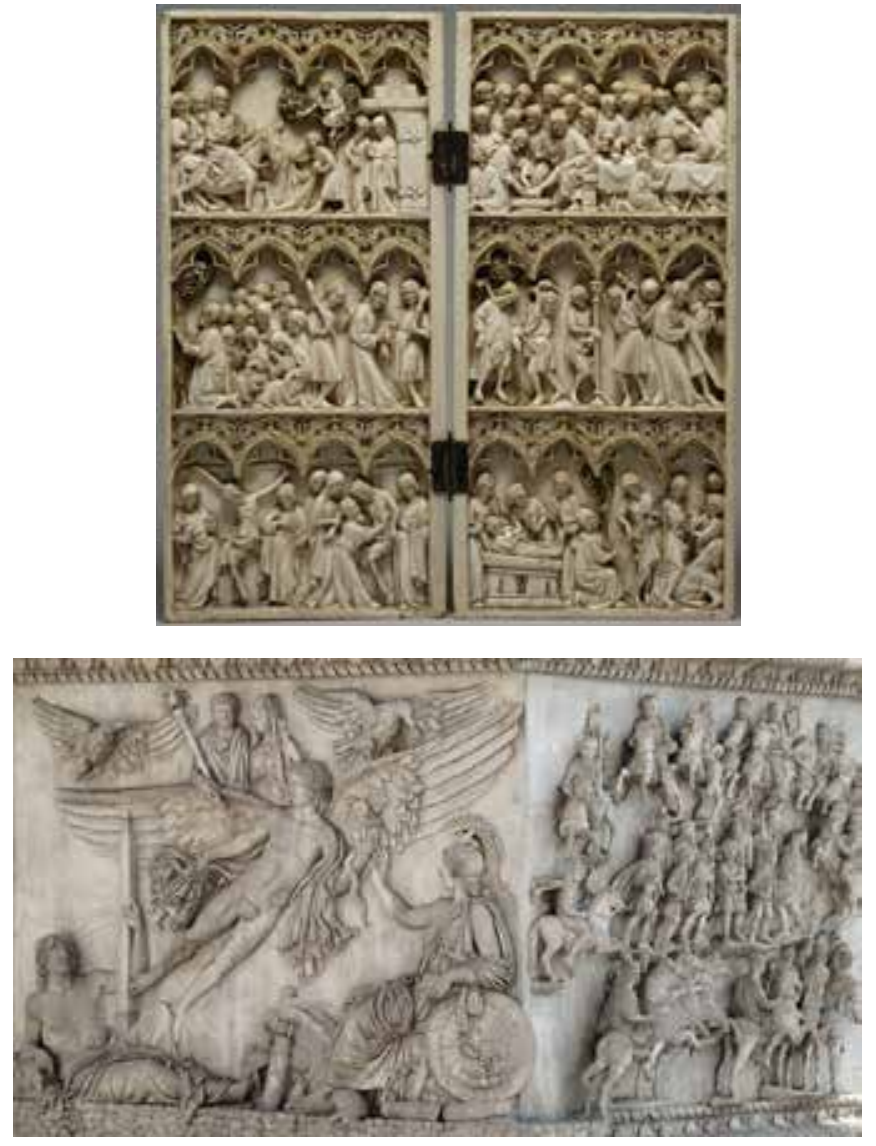

Resim 10. Pius Antoninus'un şerefine dikilmiş olan taşın kaidesi, M.S.160-170, Vatikan.

Resim 11. ‘Isa’nın Yaşamı’, Gotik, 1350-1365, Fransa.

Gotik sanatta yapı ve heykel bir bütünü oluşturur. "Çok parçalı yapı yüzeylerinde, binlerce heykelin yer alması, Hint pagoda ve stupaları ile benzerlik gösterir." (Turani, 2003: 246). Duvara arkasını vermiş bir dizi heykel grubu mimarinin bir parçası gibi kullanılır (Resim 11). Lorenzo Ghiberti'nin Floransa'daki vaftiz kilisesinin iki portali için yaptığı bronz kapısı, Gotik süslemenin dört yapraklı floral alanlarla sağlanan tasvirleriyle sınırlanmıştır. 'Cennetin Kapıları' çalışması on büyük dikdörtgen alana bölünmüş ve bu yolla betimlemeye daha ressamsı bir yaklaşım kazandırılmıştır. Rönesans'ın gelişini müjdeleyen motiflerin klasikleştirilmesinin yanı sıra Gotik sanatın yüceltilmesi de sağlanmıştır (Avery, 2015) (Resim 15). 


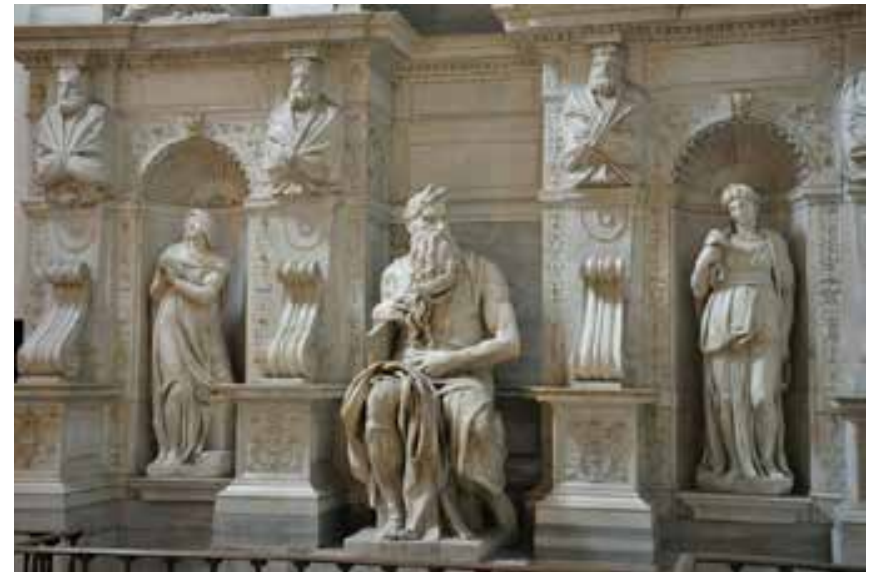

Resim 12. 'Musa', Michelangelo, 1513-1515, mermer, San Pietro in Vincoli, Roma.

Rönesans döneminin en önemli sanatçılarından “Michelangelo, başlangıçta Donatello'nun yüzeysel oyma tekniği ile rölyef denemeleri yapmış, daha sonra etrafında dönülebilen anıtsal heykellerin oyma işine yoğunlaşmıştır. Sanatçının asıında taş blok yüzeyine kendine özgü oyma tekniğiyle biçimlendirdiği örneklerini, çağdaşlarının klasik rölyef heykelin bir devamı olarak gördükleri açıktır." (Avery, 2015).

"Rölyefte düzlemin ne zaman değerden düşmeye başladığını bilmek istersek, Michelangelo'nun son devresindeki eserlerini incelememiz yerinde olur. II. Julius'un mezarında Michelangelo Musa’yı düzlemin o kadar ilerisine koymuştur ki artık bu bir "kabartma" figür değildir, hiçbir düzleme girmeyen, her yanından görülebilecek bağımsız bir heykel olarak kabul edilmesi zorunludur. Bununla figür ve nişin genel problemine gelmiş oluyoruz. Illkellerde yerleşmiş bir görüş yoktur: kimi vakit figür nişin içinde görünmez olmuştur, kimi zaman nişten dışarı çıkar. Klasiklerde kural, bütün plastikleri duvarın derinliğine, içerlek olarak yerleştirmektir. Bunlarda figür canlanmış bir duvar parçasından başka bir şey değildir. Bu daha Michelangelo zamanında değişti, Bernini'de artık nişi dolduran figürlerin dışarı taşması tabii idi. Boş uzay artık kompozisyona bir faktör olarak katılmıştır." (Wölfflin, 1990: 137-138) (Resim 12).
Barok heykeltıraşlar, bu tür yanılsamalı denemeleri, genelde büyük ölçekli olarak devam ettirmişlerdir. "Bunların büyük rölyef kompozisyonları derin kutu benzeri çerçevelerle ve özel sahne tasarımı ışıklandırması ile dengelenerek mermerden bir çeşit resim unsuru haline gelmiştir. Lorenzo Bernini'nin 'Azize Teresa'nın Vecdi' çalışması, bir mermer altar etrafında oyulan figürleriyle, bu duruma etkileyici bir örnek sunmaktadır." (Britannica, 2014). Diğer örneklerde de belirgin şekilde figürlerin kopması görünür ancak yine de zeminle bağlantılıdır. Biraz daha içeri doğru girinti yaparak, alçak rölyef şeklinde oyulmuş örnekler de vardır. Aşırı kısaltma yaygın olarak kullanılarak, tüm sahne perspektif olarak içeri doğru giren, geriye itilen arka plana göre sergilenmektedir.

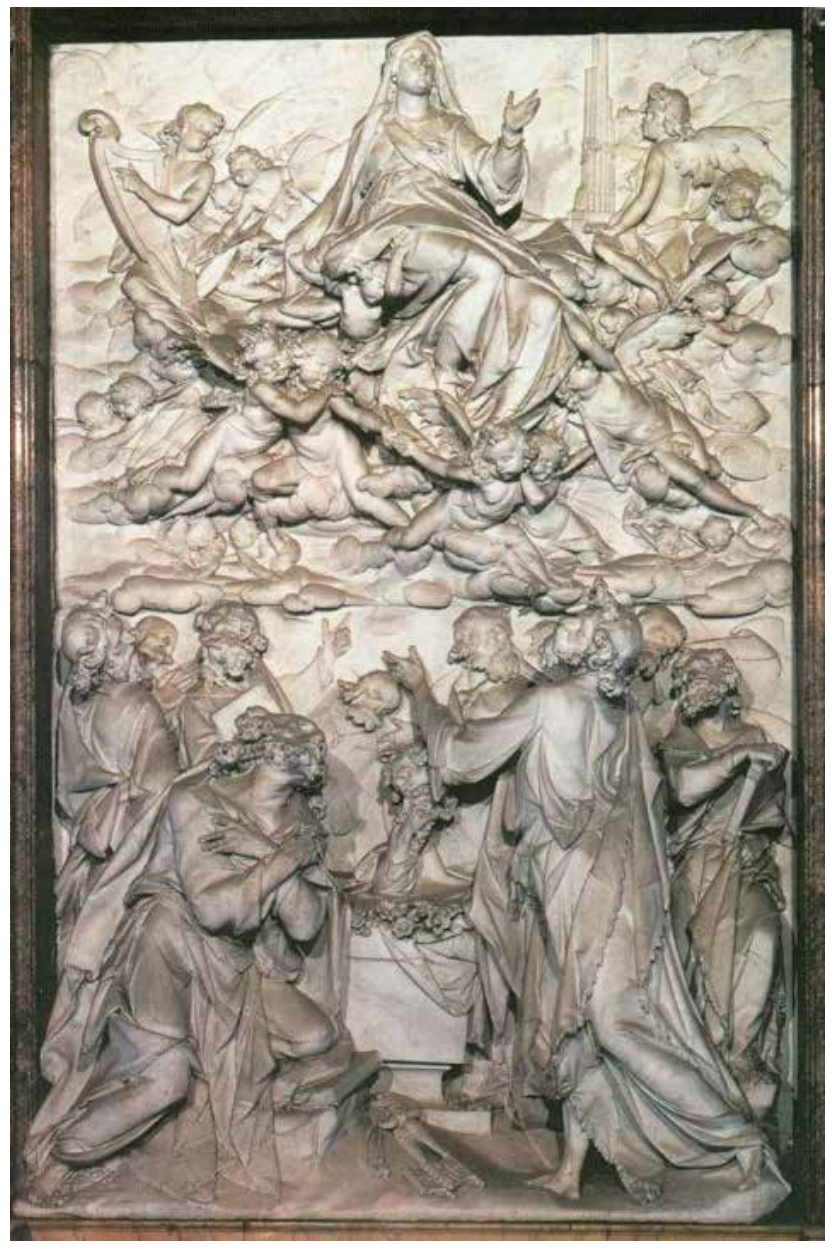

Resim 13. 'Santa Maria Maggiore', Bernini, 1607-10, mermer, Roma. 


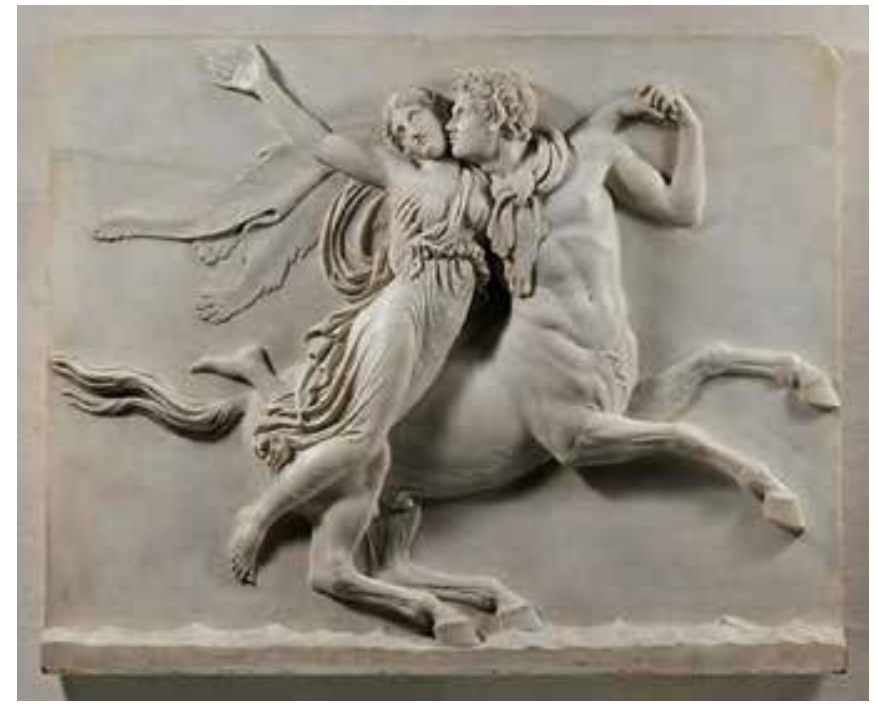

Resim 14. ‘Nessus Deianira’yı Kaçırıyor', Bertel Thorvaldsen, 1814, mermer.

Erken 19. yüzyılın neoklasik sanatçıları, klasik canlanma ve safık (yalınlık) olarak gördükleri şeylerin izinde, alçak rölyefle yapılan daha önceki deneme yanılmaları canlandırmışlardır. Bu tür çalışmalar, etkilerinin arttırılması için ince yüzey modellemeye ve tasarımın belirginliğine dayaniyordu. Antonio Canova ve Bertel Thorvaldsen'in eserleri bu anlamda karakteristiktir. Thorvaldsen'in Deinira'yı Kaçıran Nesus adlı yüksek rölyef çalışmasında, Deianira'nın kolu, Gentaur'un boynu etrafına sıkıca sarılan aslan derisinin alçak rölyefine karşı boşluğa doğru uzanır gözükmektedir. Giysinin keskin tanımlı kıvrımları onu Gentaur'un çıplak bedeninden ayırt ederken akan çizgileri, hareket duygusunu canlı ve yoğun şekilde aktarmaktadır (Wardropper, 2006: 143) (Resim14).

Rönesans rölyef kavramı, kendisine özgü olanaklarıyla varlı̆̆ını devam ettirmiş ve François Rude, Rodin gibi sanatçılar tarafından yoğun ve belirgin şekilde kullanılmıştır. Yirminci yüzyılın değişen ifade, biçimlendirme ve malzeme çeşitliliği yansımalarını rölyef heykelde de bulmuştur. Rodin'in 'Cehennemin Kapıları' rölyefi, 20. yüzyılın başlangıcındaki bu kırılma döneminde gerçekleşir. Sanatçı, Rönesans'tan ve en çok Michelangelo'dan aldığı
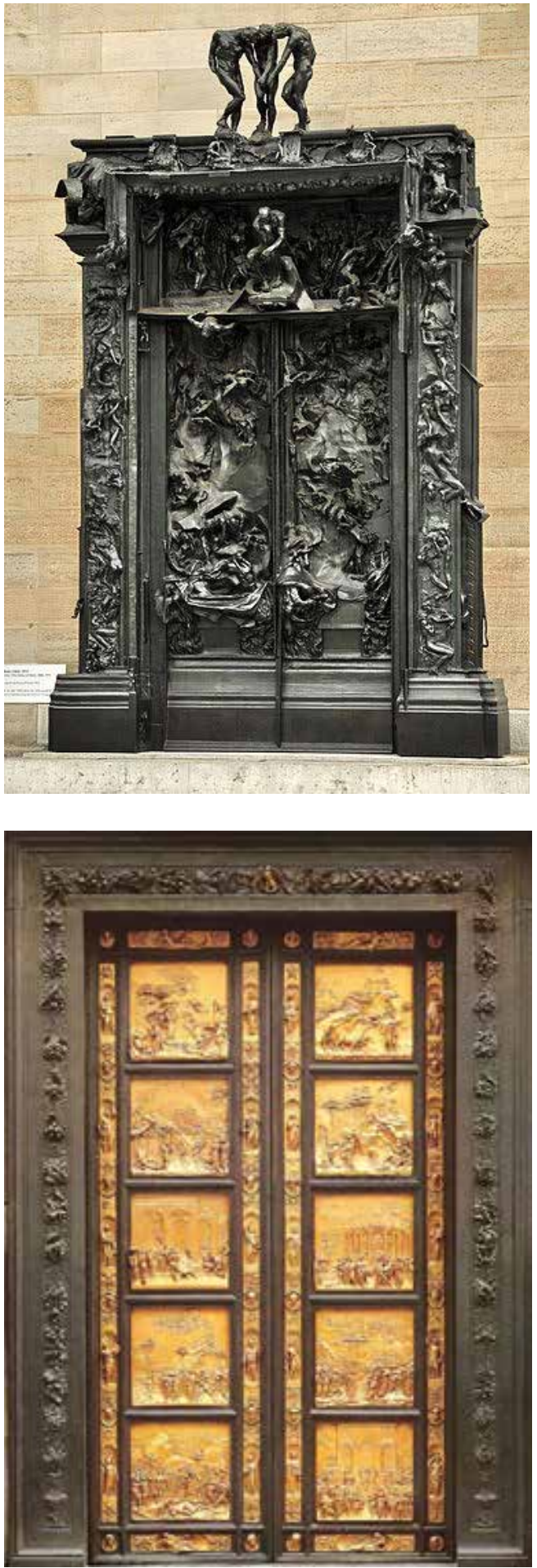

Resim 15. 'Cennetin Kapıları', Lorenzo Ghiberti 1378-1455, Floransa.

Resim 16. 'Cehennemin Kapıları', Rodin, 1840-1917, bronz, Paris. 
ilhamla kendi dönemi arasında köprü kurmuş, Van Gogh, Gauguin ve Cezanne'nin resimde yaptıklarını heykelde yakalamıştır.

“Michelangelo'nun II. Julius mezarı için tasarladığı Köleleri'ni, taştan yontulmuş deli gömleklerinden çekip çıkararak onlara şehvet hissi veren Rodin'dir. Bütün bunların ötesinde, karşı konulamaz etkileyiciliği, çırpınışlarıyla mermer yüzeyinde beliren ve şehvetli olmaktan çok, umutsuz gibi görünen yaratıkları ile 'Cehennemin Kapıları', uzun süre heykele egemen olan donuk ve akademik eğilimi birdenbire sonlandırmış oldu." (Neret, 1994: 7).

Lorenzo Ghiberti’nin ‘Cennetin Kapıları'ndaki düzenli, planlı, alçak, ince modellemesine karşılık Rodin'in ‘Cehennemin Kapıları', huzursuz, hareketli, kapı zemininin dışına fırlayan yüksek form modellemesiyle tam bir tezat oluşturmaktadır (Resim 15-16). Rodin rölyef zemininin dışında birçok figür yapmış, daha sonra onları diğer figürlerin arasına yerleştirmiş, bazılarını söküp yeniden konumunu belirlemek için bir sürü deneme gerçekleştirmiştir. Doğaçlama diyebileceğimiz yöntemle oluşturulan kapıdaki figürlerin birçoğu sonrasında 'Düşünen Adam' heykeli gibi kendi başına sergilenerek, bağımsızlığını da kazanmıştır.

Modern sanat 20. yüzyılın ilk yıllarına kadar figüratifti. Nesneyi silikleştiren Turner ve Monet gibi öncülerin ardından, Picasso'nun Avignon'lu Kızlar'ıyla birlikte, figür (nesne) temsili parçalanmış; bu sürece soyutlama, ortaya çıkan çalışmalara soyut (ya da non-figüratif) denmiştir. Nesne temsilinden kurtulma düşüncesi ve yöntem, 20. yüzyıın ilk yarısında o kadar vurgulanmıştır ki soyut sanat kavramı neredeyse modern sanatla eşanlamlı kullanılır hale gelmiştir (Yılmaz, 2013: 27).

Nesneye bakışta gerçekleşen bu büyük dönüşüm, rölyef heykelde de yansımalarını non-figüratif örneklerde bulmuştur. Birinci dünya savaşının sonunda, savaşı ve ölenlerini anmaya yönelik örnekler, modern rölyef tarzına uygulama alanı sağlamıştır.

\section{Sonuç}

Rölyef heykel, en eski sanat formlarından biridir ve günümüze kadar kesintisiz bir rol oynamıştır. Kullanılan kalıcı malzemeler sayesinde bu sanat formu tarihi olaylar ve dinlerin görsel kaydını yaratmada, geçmişin büyük uygarlıklarının çoğunun arşivini oluşturmada işlev görmüştür.

Mısır'da taş bina duvarları üzerinde keskin hatlarla zemin düzleminden içeri giren alçak rölyef örnekleri, Antik Yunan'da, Ortaçağ Avrupa'sında ve Gotik'te kilise duvarlarını süsleme amaçlı yüksek rölyef örnekleri, Rönesans'ta hassas, alçak ve güçlü heykelsi etki yaratan yüksek rölyef ve bunların çarpıcı kompozisyon illüzyonlarının bir arada kullanıldığı örnekler vardır. Barok heykeltıraşlar, bu tür yanılsamalı denemeleri, genelde büyük ölçekli olarak devam ettirmişlerdir.

Zemine zorunlu bir bağılığı olmasına rağmen bu sanat formunun figüratif örnekleri heykeltıraşa, form geliştirme ve hacimle ilgili deneyimlerini arttırma olanağı verir. Kimi zaman yanılsamalı bir alan yaratarak, biçimlendirme, yüzey modelleme, formun vurgulanması, ışık-gölge etkilerinin araştırılabileceği bir alan açan rölyef heykel düzlemi üzerinde gerçekleşen bu süreci, örnekleri inceleyerek ve bizzat uygulayarak tecrübe etmek, serbest duruş heykelin gerçekliğinin daha iyi algılanmasını, bu karşılaştırmalı yolla hacim duygusunun gelişmesini sağlar.

20. yüzyılın değişen ifade şekilleri içerisinde bu temel sanat formunu anlamak, figüratif rölyef heykel örneklerini incelemek, geleneksel heykeltıraşlık ve sanat eğitimi açısından derinliğin yanılsamalı ve gerçek boyutuyla ilgili önemli bir plastik deneyim sunar.

\section{Kaynakça}

Boström Antonia (2004). The Encyclopedia of Sculpture, Volume 3, New York: Taylor/Francis Group.

Gombrich, E.H. (1989). Sanatın Öyküsü, çev: Bedrettin Cömert, İstanbul: Remzi Kitabevi. 
Neret, Gilles (1994). Auguste Rodin , çev: Chris Miller, Köln: Benedikt Taschen.

Ocvirk, Otto G., Stinson, Robert E., Wigg, Philip R.,Bone, Robert 0.,Cayton, David L. (2015). Sanatın Temelleri, Izmir: Karakalem Yayınevi.

Rogers, L.R. (1969). Sculpture, New York: Oxford University Press. Rona, Zeynep; Beykan, Müren (1997). Eczacıbaşı Sanat Ansiklopedisi, İstanbul: Yem Yayınevi.

Wölfflin, Heinrich (1990). Sanat Tarihinin Temel Kavramları, çev: Hayrullah Örs, İstanbul: Remzi Kitabevi.

Turani, Adnan (2003). Dünya Sanat Tarihi, İstanbul: Remzi Kitabevi. Wardropper, Ian (2006). "Bertel Thorvaldsen's “Nessus Abducting Deianira”, Metropolitan Museum Journal (41): 141-154.

Yılmaz, Mehmet (2013). Modernden Postmoderne Sanat, Ankara: Ütopya Yayınevi.

\section{Internet Kaynakları}

Advey, Charles (1996). Relief Sculpture, Oxford University Press, (Grove Art Online: DOI:10.1093/gao/9781884446054.article. T071316) http://www.oxfordartonline.com/subscriber/article/grove/ "art/T071316

Encyclopedia Britannica (2014). Erişim Numarası: 87324628 http://search.ebscohost.com/login.aspx?direct=true $\& d b=$ ers $\& A N=87324628 \&$ lang $=$ tr $\&$ site $=$ eds - live $\&$ scope $=$ site

Visual Arts Encyclopedia, "Relief Sculpture" http://www.visual-arts-cork.com/sculpture/relief.htm (29.04.2015).

\section{Görsel Kaynaklar}

Resim 1. Laussel Venüsü (M.Ö 23.000), Paleolitik, Fransa. https://beckchris.wordpress.com/visual-arts/art-history101-part-i-prehistoric-era-1399-ce/ (29.04.2015).

Resim 2. Akhenaten, Nefertiti ve çocukları. http://tr.wikipedia.org/wiki/Akhenaton, Erişim Tarihi:29-05-2015.

Resim 3. Apsara Dansçıları, Oyma, Angkor Wat Wall http://www.travelingmark.com/cambodia/angkor-wat/, Erişim Tarihi:29-04-2015.

Resim 4. Ashurbanipal Aslan Avı, M.0̈. 645-635, Ninevah, Irak. https://beckchris.wordpress.com/visual-arts/art-history101-part-i-prehistoric-era-1399-ce/ (29.04.2015).

Resim 5. 'Anahtarları Aziz Peter'e veren İsa', Donatella, 1428-30, mermer, Floransa- İtalya. Victoria and Albert Müzesi, Londra. http://www.vam.ac.uk/content/articles/t/donatellosascension-relief/ (29.04.2015).
Resim 6. 'İsa’nın Vaftiz Edilişi', Ghiberti, 1427, tunç. http://www.viaesiena.it/uploads//viaesiena/storie_sgb_4_ Lensini.jpg (29.04.2015).

Resim 7. 'Meryem ve İsa', Desiderio da Settignano, 1460, mermer, İtalya.

http://collections.vam.ac.uk/item/096302/virgin-and-childrelief-desiderio-da-settignano/ (29.04.2015).

Resim 8. Hegeso, M.0̈. 400, Ulusal Arkeoloji Müzesi. Atina http://counterlightsrantsandblather1.blogspot.com. tr/2012/10/liberty-part-1_6.html (29.04.2015).

Resim 9. Efes, Nike (Zafer) tanrıçası tapınağı kanatlı melek figürleri.

http://wanderingwalnuts.blogspot.com.tr/2008/06/izmirancients-and-rugs.html, (29.04.2015).

Resim 10. Pius Antoninus'un şerefine dikilmiş olan taşın kaidesi, M.S.160-170, Vatikan. https://classconnection.s3.amazonaws.com/144/ flashcards/2678144/jpg/ca006-13EA6962B5559CDE185.jpg (29.04.2015)

Resim 11. 'İsa'nın Yaşamı', Gotik, Fransa, 1350-1365. http://upload.wikimedia.org/wikipedia/commons/3/3e/ French_Diptych_with_Scenes_from_the_Passion_of_ Christ_-_Walters_71179_-_Open.jpg (29.04.2015).

Resim 12. 'Musa', Michelangelo, 1513-1515, mermer, San Pietro in Vincoli, Roma. http://4.bp.blogspot.com/HZ_VWxtcDXE/U40B_x3MiKI/ AAAAAAAAAaU/WC-C-0zAKco/s1600/DSC_0030.JPG (29.04.2015).

Resim 13. 'Santa Maria Maggiore', Bernini, 1607-10, mermer, Roma.

http://www.wga.hu/frames-e.html?/html/b/bernini/pietro/ index.html (29.04.2015).

Resim 14. 'Nessus Deianira’yı Kaçırıyor', Bertel Thorvaldsen, 1814 mermer.

http://www.metmuseum.org/collection/the-collectiononline/search/231004 (29.04.2015).

Resim 15. 'Cennetin Kapıları', Ghiberti, 1425-52, Floransa. http://www.poderesantapia.com/images/art/lorenzoghiberti/ paradise700.jpg (29.04.2015).

Resim 16. 'Cehennemin Kapıları', Rodin, 1880-1917, bronz, Paris http://duckmarx.blogspot.com.tr/2012/11/trajan-53-117. html (29.04.2015). 